\title{
Infant feeding in coeliac disease
}

\author{
K. M. JONES ${ }^{1}$, E. M. PRINGLE, K. B. TAYLOR ${ }^{2}$, AND W. F. YOUNG \\ From the Queen Elizabeth Hospital for Children, London
}

EDITORIAL SYNOPSIS The duration of breast feeding and the time of introduction of cereals into the diet was studied in patients with coeliac disease and controls but no significant differences were found. These results do not, however, invalidate the idea that some cases of coeliac disease are due to an immunological hypersensitivity to gluten.

Two theories are currently entertained to explain the harmful effects of wheat and rye gluten in patients with coeliac disease. One postulates a congenital deficiency of a proteolytic enzyme in the small gut, the other that the mucosal lesion is an expression of immunological hypersensitivity to gliadin. The two theories are not mutually exclusive. If hypersensitization occurs, this must be in response to ingested gliadin. Infants absorb cow's milk protein in an antigenic form (Anderson, Schloss, and Myers, 1925; Lippard, Schloss, and Johnson, 1936); the same may be true of wheat gliadin. There is the possibility that in infancy certain components of the diet may set in train a variety of immunological responses which play a part in determining later liability to certain diseases, and modern theories of immunological tolerance suggest that the age at which potential antigens are first presented to the infant may be critical. Acheson and Truelove (1961) found a significant excess of individuals who had been weaned from the breast during the first two weeks of life in a group of patients with ulcerative colitis, compared with matched healthy controls, but no difference was discernible when those weaned at four weeks were considered. The causal link between wheat gluten and coeliac disease is stronger at present than that between ulcerative colitis and milk proteins. These considerations prompted this study of the age at which cereals were introduced into the diet of children who subsequently developed coeliac disease and, since in some cases of coeliac disease milk has been implicated as a possible causal or aggravating factor (Kunstadter and Schultz, 1953; Breton, Vandendorp, and Dubois, 1959; Taylor, Thomson, Truelove, and Wright, 1961), the age at which cow's milk was first introduced.

${ }^{1}$ Member of the M.R.C. Statistical Research Unit

${ }^{2}$ Member of the M.R.C. Gastroenterological Research Unit. Present address: Stanford University School of Medicine, Palo Alto, California.

\section{MATERIALS AND METHODS}

Information about diet in infancy was obtained from the mothers of 20 patients with coeliac disease attending the Out-patient Department of the Queen Elizabeth Hospital, using a standard questionnaire. Eleven patients were males; ages ranged from 12 years to under 1 year. The diagnosis of coeliac disease was established by evidence of malabsorption, especially of fat, by the radiological appearances of the small bowel, and by the therapeutic response to a gluten-free diet. It was confirmed in 13 cases by jejunal biopsy.

Two groups of control subjects were selected. One consisted of 40 children, who were attending the Outpatient Department of the same hospital on the same days as the coeliac children. These children were matched with the coeliac children by sex and by age to within three months.

A second control group consisted of 20 children with fibrocystic disease of the pancreas, diagnosed on the basis of low duodenal tryptic activity and high sodium chloride content of sweat, matched similarly by age and sex with the coeliac group. This disease was chosen because it affects the intestinal tract and clinically has certain features in common with coeliac disease, yet differs from it in that is has a well-established genetic basis. Children with this complaint are liable to feeding difficulties in infancy. However, the circumstances of early life differed in that the children with cystic fibrosis tended to be admitted to hospital earlier in life and for longer periods than the coeliac children. As a result the mothers of such infants were oiten ignorant of their children's diet in the early months of infancy and, in addition, premature cessation of maternal breast feeding may have been a direct consequence of the admission of the child to hospital.

THE QUESTIONNAIRE The questions put to each informant were as follows:-

1 What was the duration in weeks of breast feeding, either complete or partial?

2 At what age was cow's milk introduced into the diet?

3 At what age was food first introduced into the diet?

4 At what age was any cereal introduced into the diet? 
5 Did this cereal cause any disturbance in the child?

6 Does any particular food or drink upset the child at present?

The answers to these questions comprise the data presented in this paper.

\section{RESULTS}

INTRODUCTION OF CEREAL The time of introduction of cereal into the diet was elicited in 19 out of 20 cases of coeliac disease, in 12 out of 20 cases of fibrocystic disease, and in 39 out of 40 cases in the main control group. The results are shown in Table $\mathrm{I}$.

\section{TABLE I}

AGE AT INTRODUCTION OF FIRST CEREAL INTO THE DIET

\begin{tabular}{|c|c|c|c|c|c|c|c|c|}
\hline \multirow[t]{2}{*}{$\begin{array}{l}\text { Mean Time } \\
(w k .)\end{array}$} & \multicolumn{7}{|c|}{$\begin{array}{l}\text { Age (mth.) of Introduction of } \\
\text { First Cereal in Diet }\end{array}$} & \multirow[t]{2}{*}{$\begin{array}{l}\text { Total } \\
\text { Cases }\end{array}$} \\
\hline & $<1$ & $1-$ & $2-$ & 3 & 4 & & $6-$ & \\
\hline $12 \cdot 56$ & 0 & 6 & 6 & 4 & 1 & 2 & 0 & $19^{1}$ \\
\hline $\begin{array}{l}14 \cdot 67 \\
12 \cdot 58\end{array}$ & $\begin{array}{l}0 \\
0\end{array}$ & $\begin{array}{l}2 \\
9\end{array}$ & $\begin{array}{r}3 \\
14\end{array}$ & $\begin{array}{r}3 \\
12\end{array}$ & $\begin{array}{l}3 \\
3\end{array}$ & 1 & $\begin{array}{l}0 \\
0\end{array}$ & $\begin{array}{l}12^{2} \\
39^{1}\end{array}$ \\
\hline
\end{tabular}

${ }^{1}$ Excludes one in which the details were unknown.

${ }^{2}$ Excludes eight in which the details were unknown (patients were in hospital throughout early infancy).

The mean period before cereal was first presented was similar in all three groups and the detailed breakdown by months shows no substantial difference between them. In the coeliac group, in 17 out the 19 cases in which information was obtained, wheat was the cereal implicated, and in the other two it was oats. In 36 cases in the main control group, wheat was the first cereal to be introduced, in two cases it was oats and in one, barley.

DURATION OF BREAST FEEDING ONLY The length of the period between birth and the time when cow's milk was first introduced into the diet was established in the case of all the coeliac subjects, in 18 out of 20 patients with mucoviscidosis, and in 39 out of 40 controls. The mean duration for each group and a breakdown by months are presented in Table II. Again, no obvious differences were found between the means or the distributions in the three groups.

TABLE II

\begin{tabular}{|c|c|c|c|c|c|c|c|c|c|}
\hline \multicolumn{10}{|c|}{ DURATION OF COMPLETE BREAST FEEDING } \\
\hline & \multirow{2}{*}{$\begin{array}{l}\text { Mean } \\
\text { Duration } \\
(w k .)\end{array}$} & \multicolumn{7}{|c|}{$\begin{array}{l}\text { Age (mth.) of Introduction of } \\
\text { Cow's Milk }\end{array}$} & \multirow[t]{2}{*}{$\begin{array}{l}\text { Total } \\
\text { Cases }\end{array}$} \\
\hline & & $<1$ & $1-$ & $2-$ & 3 & 4 & $5-$ & $6-$ & \\
\hline $\begin{array}{l}\text { Coeliac disease } \\
\text { Fibrocystic }\end{array}$ & $4 \cdot 3$ & 11 & 5 & 2 & 1 & 1 & - & - & 20 \\
\hline disease & $7 \cdot 5$ & 8 & 4 & 1 & 1 & 3 & 1 & - & $18^{1}$ \\
\hline Controls & $5 \cdot 6$ & 17 & 8 & 6 & 6 & 1 & 1 & - & $39^{2}$ \\
\hline
\end{tabular}

DISTURBANCES CAUSED BY CEREALS OR OTHER FOODS No significant pattern emerged from the answers to these questions.

\section{DISCUSSION}

Most if not all patients with coeliac disease react abnormally to wheat gluten and respond to a glutenelimination diet, and it seemed that an investigation of infant diets in this disease offered fruitful possibilities. It appears that in the case of coeliac disease neither the time of weaning nor of introduction of gluten into the diet differ significantly from the times established in matched controls. The present study suggests that neither factor plays a major part in the causation of, or predisposition to, coeliac disease. However, before accepting this negative conclusion as proven, it would be desirable that similar studies should be made in other centres, in view of the present ignorance about the causation of coeliac disease.

The findings as regards breast feeding and weaning contrast with those of Acheson and Truelove (1961) in ulcerative colitis, a disease in which, as in coeliac disease, abnormally high titres of antibodies to cow's milk proteins are found (Taylor and Truelove, 1961). However, our results do not mean that the idea of an immunological mechanism causing coeliac disease is invalidated; it is possible that some individuals may develop hypersensitivity to wheat gluten, although they do not differ from normal individuals in respect to the time of weaning or the time of introduction of gluten into their diets.

We are grateful to Dr. Richard Doll and Dr. S. C. Truelove for helpful advice, and to Miss Longstaff and the dietitians of the Radcliffe Infirmary, Oxford for their help in obtaining details of the contents of proprietary cereals.

\section{REFERENCES}

Acheson, E. D., and Truelove, S. C. (1961). Early weaning in the aetiology of ulcerative colitis. Brit. med. J., 2, 929-933.

Anderson, A. F., Schloss, O. M., and Myers, C. (1925). The intestinal absorption of antigenic protein by normal infants. Proc. Soc. exp. Biol. (N.Y.), 23, 180-182.

Breton, A., Vandendorp, F., and Dubois, O. (1959). L'effect pathogène du gluten au cours de la maladie coeliaque: déficit enzymatique ou réaction allergique? Pédiatrie, 14, 5-20.

Kunstadter, R. H., and Schultz, A. (1953). Gastrointestinal allergy and the celiac syndrome with particular reference to allergy to cow's milk. Ann. Allergy, 11, 426-434.

Lippard, V. W., Schloss, O. M., and Johnson, P. A. (1936). Immune reactions induced in infants by intestinal absorption of incompletely digested cow's milk protein. Amer. J. Dis. Child., $51,562-574$.

Taylor, K. B., Thomson, D. L., Truelove, S. C., and Wright, R. (1961). An immunological study of coeliac disease and idiopathic steatorrhoea: serological reactions to gluten and milk proteins. Brit. med. J., 2, 1727-1731.

_- and Truelove, S. C. (1961). Circulating antibodies to milk protein in ulcerative colitis. Jbid., 2, 924-929. 